\title{
Study on Genetic Variability, Heritability and Genetic Divergence for Character Association in Cucumber (Cucumis sativus L.) under Prayagraj Agro - Climatic Conditions
}

\author{
Yogesh Kumar*, Samir Ebson Topno and Vijay Bahadur
}

Department of Horticulture, Naini Agricultural Institute, Sam Higginbottom University of Agriculture, Technology and Sciences, Prayagraj, (Uttar Pardesh), India

*Corresponding author

\section{Keywords}

Cucumber, Genetic variability,

Correlation, path coefficient, Genetic divergence growth and yield

\section{Article Info}

\section{Accepted:}

20 December 2020

Available Online:

10 January 2021

\section{A B S T R A C T}

An experiment was conducted on Genetic variability, correlation, path coefficient and genetic diversity $\mathrm{D}^{2}$ analysis in the 16 genotypes of Cucumber during 2019-20 at the Horticulture Research Field, Department of Horticulture, Sam Higginbottom University of Agriculture, Technology and Sciences, Prayagraj. The observations were recorded on various growths and yield attributes. The experiment was carried out with 16 genotypes procured from Local market of Prayagraj in randomized Block Design (RBD) with three replications. The results from the present investigation revealed that genotypes Swarn Agati identified as high fruit yield per vine, fruit yield per plot $(\mathrm{kg})$ fruit yield $\left(\mathrm{t} \mathrm{ha}{ }^{-1}\right)$ at Prayagraj Agro-climatic condition. The genotypic and phenotypic coefficient variance value were categorized as low (0-10\%), moderate (10-20\%) and high (20\% and above). The heritability was categorized as low (0-30\%), moderate (30-60\%) and high (60\% and above).The Genetic advance and Genetic advance as percent mean was categorized as low (0-10\%), moderate (10-20\% and ( $\geq 20 \%)$. Genotypic and phenotypic correlation coefficient analysis revealed that yield (t/ha) showed positive significant association with Germination \%, Vine Length $(\mathrm{cm})$, No. of Secondary Branches, Fruit Length $(\mathrm{cm})$, Fruit Diameter (cm), No. of Fruits per Vine, Avg. Fruit Weight (g), Yield per Vine (kg) and Yield per Plot $(\mathrm{kg})$. Genotypic path coefficient analysis revealed that the direct positive effect on fruit yield (t ha-1) was exhibited by germination \%,no. of secondary branches, node number to 1 st male flower, days to 1 st female flower appearance, fruit length $(\mathrm{cm})$, avg. fruit weight $(\mathrm{g})$,yield per vine $(\mathrm{kg})$ and yield per plot $(\mathrm{kg})$.Phenotypic path coefficient analysis revealed that the direct positive effect on fruit yield (t ha-1) was exhibited by germination $\%$, node number to 1 st male flower, days to 1 st female flower appearance, number to $1 \mathrm{st}$ female flower, fruit diameter $(\mathrm{cm}$, avg. fruit weight $(\mathrm{g})$ and yield per plot $(\mathrm{kg})$. On the other hand cluster I, comprised 5 genotype, cluster III comprised genotypes1 and cluster IV cluster comprised 3genotype. The inter cluster distance was maximum between cluster II and IV. Cluster I, II, III and IV was characterized by high mean value for vine length and low mean values for yield per vine $(\mathrm{kg})$. The highest contribution in manifestation of genetic divergence was exhibited by Sex Ratio (M: F), Yield per Plot (kg), Fruit Length (cm), Yield (t/ha), Fruit Diameter (cm) and Yield per Vine $(\mathrm{kg})$. 


\section{Introduction}

Cucumber (Cucumis sativus L.) is an important vegetable crop of India cultivated throughout the country. It belongs to the family Cucurbitaceous, which has 120 genera and more than 800 species and is distinct from other Cucumis species, as it has seven pairs of chromosomes $(2 n=2 x=14)$, whereas most of the other Cucumis species have 12 pairs of chromosomes, or multiple of 12 (i.e., $2 \mathrm{n}=2 \mathrm{x}=24,2 \mathrm{n}=4 \mathrm{x}=48$, etc.) (Deakin et al., 1971).Cucumber is believed to be native to India or Southern Asia, and has been apparently cultivated for the last 3000 years (De Candolle, 1886). The fruit of cucumber is said to have cooling effect, prevents constipation and useful in Jaundice and indigestion. The fruits are eaten with salt and pepper or as an ingredient of salad, pickles and rayata. The fruits are used as an astringent and antipyretic. The seed oil also has antipyretic property. Production of cucumber in India is $11,42,000$ tones from an area of 78,000 hectares (NHB, 2017-18). The nutritive value per $100 \mathrm{~g}$ edible portion of cucumber is, moisture $96.3 \mathrm{~g}$, protein $0.4 \mathrm{~g}$, fat $0.1 \mathrm{~g}$, fibre $0.4 \mathrm{~g}$, carbohydrates $2.5 \mathrm{~g}$, energy $13 \mathrm{kcal}$, calcium $10 \mathrm{mg}$, phosphorus $25 \mathrm{mg}$, iron $1.5 \mathrm{mg}$, thiamine $0.03 \mathrm{mg}$, niacin $0.2 \mathrm{mg}$ and vitamin C $7 \mathrm{mg}$ (Fagaria et al., 2012).

The scope of improvement of any crop depends upon the magnitude of genetic variability present in the available germplasm. Greater the variability in the available germplasm, better would be the chances of selecting superior genotypes (Simmonds, 1962). In cucumber too, fruits vary in shape, size, colour, maturity and taste. Genetic variability in breeding genotypes is important for successful introgression of desired traits specific genes. The genotypic and phenotypic coefficients of variability are helpful in exploring the nature of variability in the breeding populations. Determining variability in quality and quantitative traits of different cucumber genotypes will enable a breeder to know to what extent the environment affects the yield of the crop (Ahmed and Khaliq, 2007; Ullah et al., 2012). The genetic variability among cucumber genotypes have been studied (Veena et al., 2012; Yadav et al., 2012; Kumar et al., 2013 and Ranjan et al., 2015; Pandey et al., 2013).

While selecting for yield, one should take into account the improvement of yield contributing traits, provided that the association of such traits with yield is known. Moreover, correlation and path coefficient analysis have been of immense help in selecting suitable plant type. So, in order to identify the desirable genotypes, there is an urgent need to assess the existing variability for higher yield and quality under specific conditions. Hence, the present investigation was chosen to evaluate the genotypes for better parent for hybridization programme.

Correlation coefficient empowers a breeder to know the degree of association between the independent and dependent variable fruits. Path coefficient analysis measures direct influence of one variable upon another and permits separation of correlation coefficient in component direct and indirect effect, which can be used for crop improvement through selection of component traits Kumar et al., (2018).

Assessment of genetic diversity could be suitable in crop breeding for diverse applications such as identifying diverse parental genotypes. Genetic diversity is the amount of heritable variability between varieties or populations of organisms. Variability occurs from differences in DNA sequences, biochemical characteristics like protein structure or is enzyme properties, physiological properties like growth rate and morphological characters. Substantial effort 
has been directed towards collecting, preserving and evaluating genetic variability in crops (Golabadi et al., 2012).

\section{Materials and Methods}

The present study was conducted under Prayagraj agro-climatic conditions, on genetic variability, heritability, correlation, path coefficient analysis and genetic divergence in cucumber during 2019-2020 at the Horticulture Research Farm, Department of Horticulture, Sam Higginbottom University of Agriculture, Science and Technology, Prayagraj, The experiment was carried out with 16 genotypes procured from Local market of Prayagraj.

The experiment was laid out in randomized block design with three replication. The sowing was done on raised bed method with spacing of $1.0 \mathrm{~m}$ and $1.5 \mathrm{~m}$, plant to plant and row to row, respectively, each plot with 6 plants. For the analysis of this experiment observations recorded on growth, yield attributes of cucumber.

\section{Results and Discussion}

\section{Analysis of variance}

The analysis of variance for different characters is presented in table 1 . The mean sum of squares due to genotypes showed significant differences for all characters at $1 \%$ level and 5\% level of significance, indicating the presence of substantial amount of genetic variability among the cucumber genotypes.

\section{Mean performance}

Through this study an attempt was made to assess the mean performance and extent of variability in sixteen genotypes of cucumber. Table 2 depicts the mean performance of sixteen genotypes of cucumber for seventeen growth and yield characters. The highest fruit yield per vine $(3.49 \mathrm{~kg})$, fruit yield per plot $(15.24 \mathrm{~kg})$ and fruit yield $(51.17 \mathrm{t} / \mathrm{ha})$ for Swarn Agati and the lowest fruit yield per vine $(\mathrm{kg})(192.18)$, fruit yield per plot $(\mathrm{kg})$ (3.79) and fruit yield (t/ha) (192.18) was observed in var. Heena.

Table.1 Analysis of variance (mean squares) for seventeen characters in cucumber

\begin{tabular}{|c|c|c|c|}
\hline Source of Variations & $\begin{array}{c}\text { Replication } \\
(\mathbf{d f =} \mathbf{2})\end{array}$ & $\begin{array}{c}\text { Treatments (due to } \\
\mathbf{1 5})\end{array}$ & Error $=\mathbf{3 0}$ \\
\hline Germination \% & 1.473 & $175.324 * * *$ & 2.468 \\
\hline Vine Length (cm) & 0.146 & $1645.839 * * *$ & 11.679 \\
\hline No. of Secondary Branches & $1.186 *$ & $29.027 * * *$ & 0.342 \\
\hline Days to 1st Male Flower Appearance & 1.379 & $13.881 * * *$ & 0.821 \\
\hline Node Number to 1st Male Flower & 0.024 & $1.894 * * *$ & 0.083 \\
\hline Days to 1st Female Flower Appearance & $4.576 *$ & $20.115 * * *$ & 1.05 \\
\hline Number to 1st Female Flower & 0.126 & $3.878 * * *$ & 0.294 \\
\hline Days to 50\% flowering & 0.037 & $23.038 * * *$ & 1.771 \\
\hline Days Taken to 1st harvest & 1.134 & $30.416 * * *$ & 1.315 \\
\hline Sex Ratio (M: F) & 0.014 & $0.856 * * *$ & 0.007 \\
\hline Fruit Length (cm) & 1.65 & $41.749 * * *$ & 1.108 \\
\hline Fruit Diameter (cm) & 0.373 & $6.612 * * *$ & 0.323 \\
\hline No. of Fruits per Vine & 1.165 & $47.710 * * *$ & 0.962 \\
\hline Avg. Fruit Weight (g) & 7.855 & $1248.731 * * *$ & 16.583 \\
\hline Yield per Vine (kg) & 0.029 & $1.987 * * *$ & 0.011 \\
\hline Yield per Plot (kg) & 0.597 & $29.264 * * *$ & 0.311 \\
\hline Yield (t/ha) & 1.247 & $147.881 * * *$ & 3.88 \\
\hline
\end{tabular}


Table.2 Estimates of range, grand mean, phenotypic, genotypic, environmental, coefficients of variation, heritability in broad (h2bs) sense and genetic advance in per cent of mean GA for seventeen characters in cucumber genotypes

\begin{tabular}{|c|c|c|c|c|c|c|c|c|c|c|}
\hline Genetic parameters & $\begin{array}{c}\text { Germination } \\
\%\end{array}$ & $\begin{array}{c}\text { Vine } \\
\text { Length } \\
\text { (cm) }\end{array}$ & $\begin{array}{c}\text { No. of } \\
\text { Secondary } \\
\text { Branches }\end{array}$ & $\begin{array}{c}\text { Days to 1st } \\
\text { Male } \\
\text { Flower } \\
\text { Appearance }\end{array}$ & $\begin{array}{c}\text { Node } \\
\text { Number } \\
\text { to 1st } \\
\text { Male } \\
\text { Flower }\end{array}$ & $\begin{array}{l}\text { Days to 1st } \\
\text { Female } \\
\text { Flower } \\
\text { Appearance }\end{array}$ & $\begin{array}{c}\text { Number } \\
\text { to } 1 \text { st } \\
\text { Female } \\
\text { Flower }\end{array}$ & $\begin{array}{c}\text { Days to } \\
50 \% \\
\text { flowering }\end{array}$ & $\begin{array}{c}\text { Days } \\
\text { Taken } \\
\text { to 1st } \\
\text { harvest }\end{array}$ & $\begin{array}{c}\text { Sex } \\
\text { Ratio } \\
\text { (M: } \\
\text { F) }\end{array}$ \\
\hline GCV & 10.258 & 14.507 & 24.961 & 5.733 & 20.092 & 5.770 & 17.725 & 5.695 & 5.796 & 15.584 \\
\hline PCV & 10.476 & 14.661 & 25.404 & 6.250 & 21.421 & 6.229 & 19.788 & 6.367 & 6.176 & 15.770 \\
\hline$h^{2}$ (Broad Sense) & 95.900 & 97.900 & 96.500 & 84.100 & 88.000 & 85.800 & 80.200 & 80.000 & 88.100 & 97.700 \\
\hline $\begin{array}{c}\text { Genetic } \\
\text { Advancement 5\% }\end{array}$ & 15.312 & 47.572 & 6.259 & 3.942 & 1.501 & 4.811 & 2.017 & 4.906 & 6.021 & 1.083 \\
\hline $\begin{array}{c}\text { Gen.Adv as \% of } \\
\text { Mean 5\% }\end{array}$ & 20.694 & 29.569 & 50.525 & 10.833 & 38.821 & 11.011 & 32.706 & 10.495 & 11.204 & 31.724 \\
\hline
\end{tabular}

Table.3 Estimates of phenotypic, genotypic coefficients of variation, heritability in broad (h2bs) sense and genetic advance in per cent of mean GA for seventeen characters in cucumber genotypes

\begin{tabular}{|c|c|c|c|c|c|c|c|}
\hline Genetic parameters & $\begin{array}{c}\text { Fruit } \\
\text { Length } \\
\text { (cm) }\end{array}$ & $\begin{array}{c}\text { Fruit } \\
\text { Diameter (cm) }\end{array}$ & $\begin{array}{c}\text { No. of } \\
\text { Fruits per } \\
\text { Vine }\end{array}$ & $\begin{array}{c}\text { Avg. Fruit } \\
\text { Weight (g) }\end{array}$ & $\begin{array}{c}\text { Yield per } \\
\text { Vine (kg) }\end{array}$ & $\begin{array}{c}\text { Yield per } \\
\text { Plot (kg) }\end{array}$ & $\begin{array}{c}\text { Yield } \\
(\mathbf{t} / \mathbf{h a})\end{array}$ \\
\hline GCV & 20.392 & 26.142 & 25.761 & 15.560 & 42.791 & 32.554 \\
\hline PCV & 21.210 & 28.082 & 26.545 & 15.871 & 43.156 & 33.074 & 17.793 \\
\hline $\mathbf{h}^{2}$ (Broad Sense) & 92.400 & 86.700 & 94.200 & 96.100 & 98.300 & 96.900 & 92.500 \\
\hline Genetic Advancement 5\% & 7.290 & 2.777 & 7.892 & 40.930 & 1.658 & 6.299 & 13.728 \\
\hline Gen.Adv as \% of Mean 5\% & 40.388 & 50.132 & 51.501 & 31.425 & 87.405 & 66.007 & 35.256 \\
\hline
\end{tabular}


Table.4 Estimates of genotypic and phenotypic correlation coefficient between seventeen characters in cucumber genotypes

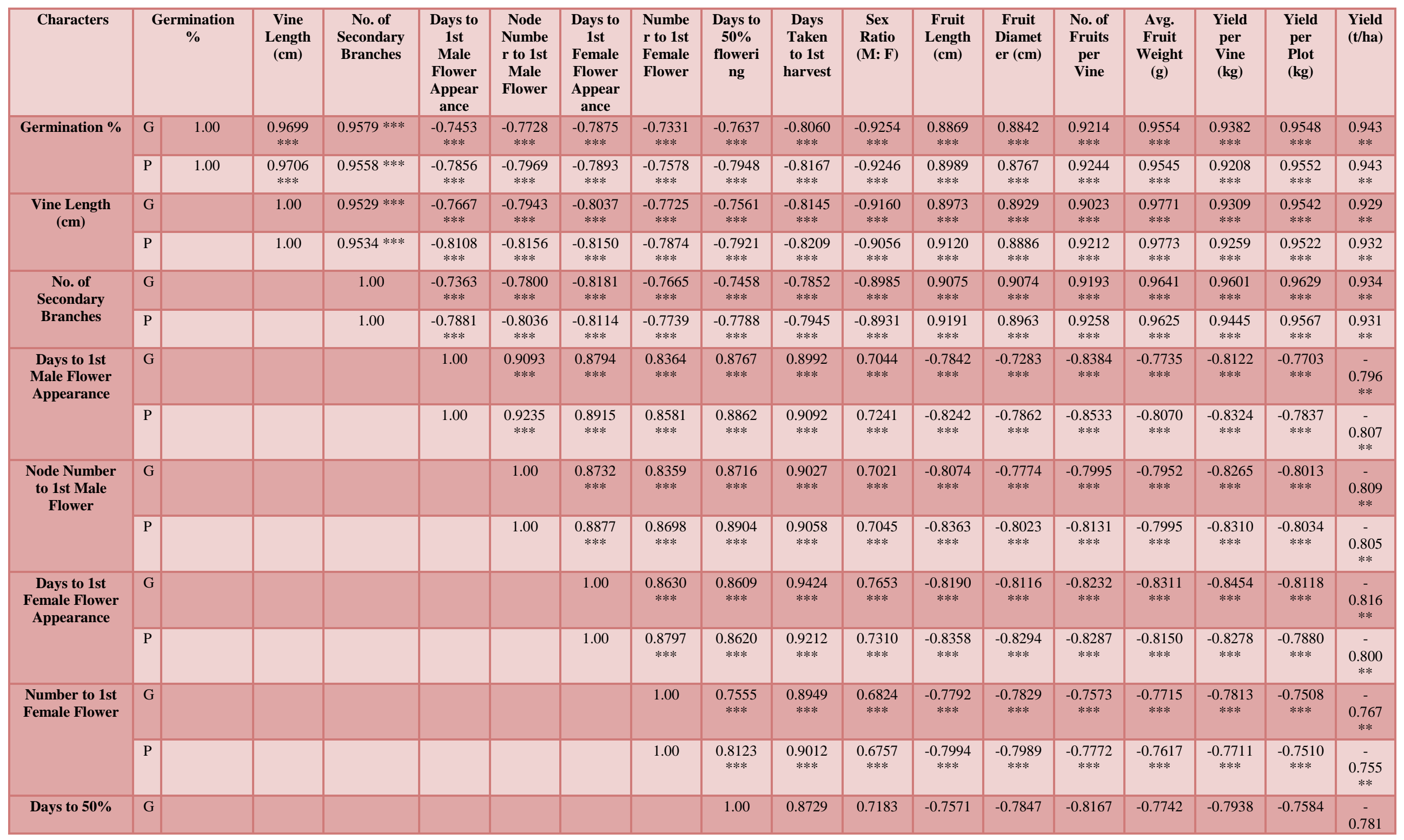




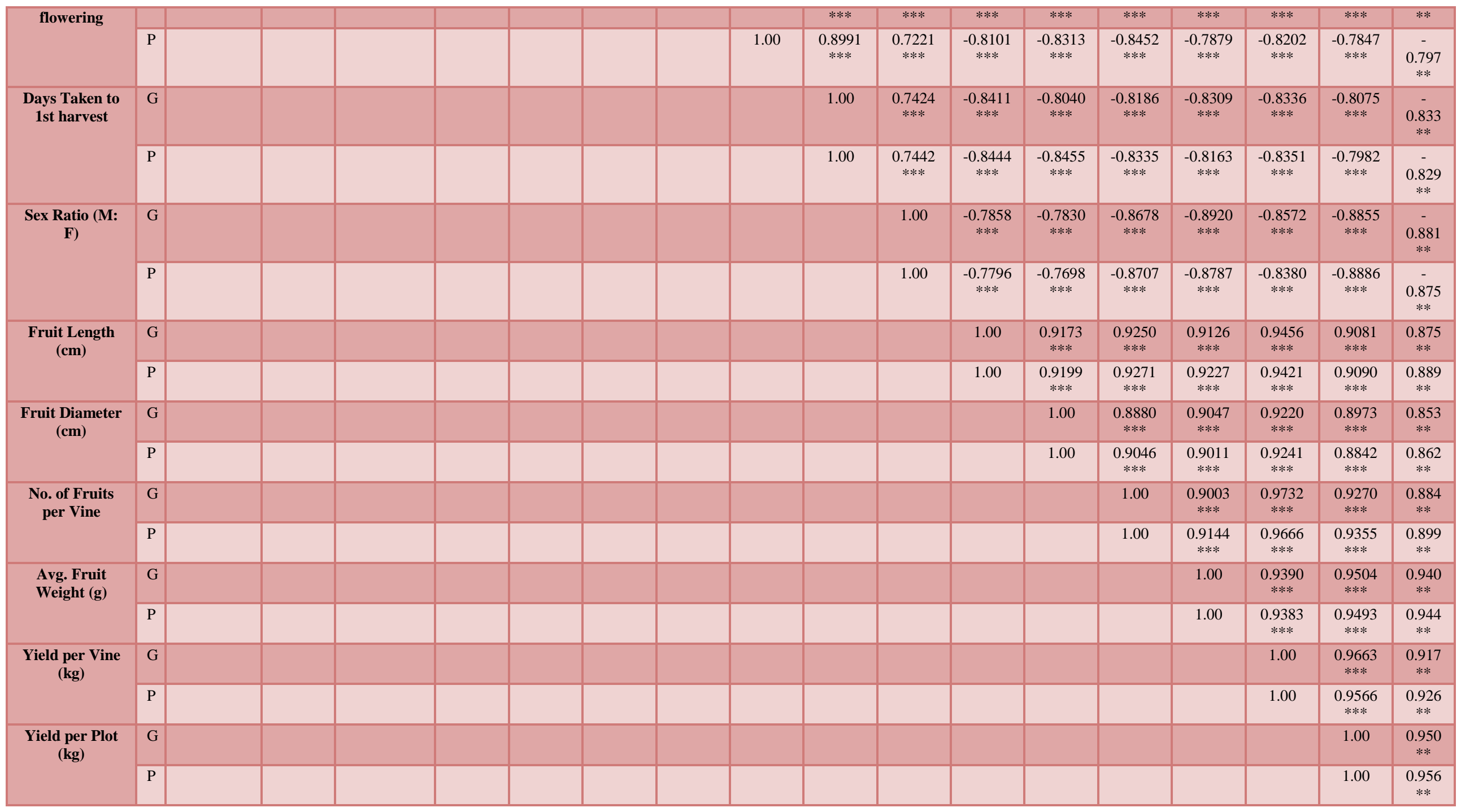


Table.5 Direct and indirect effects of seventeen characters on yield at genotypic and phenotypic level in cucumber genotypes

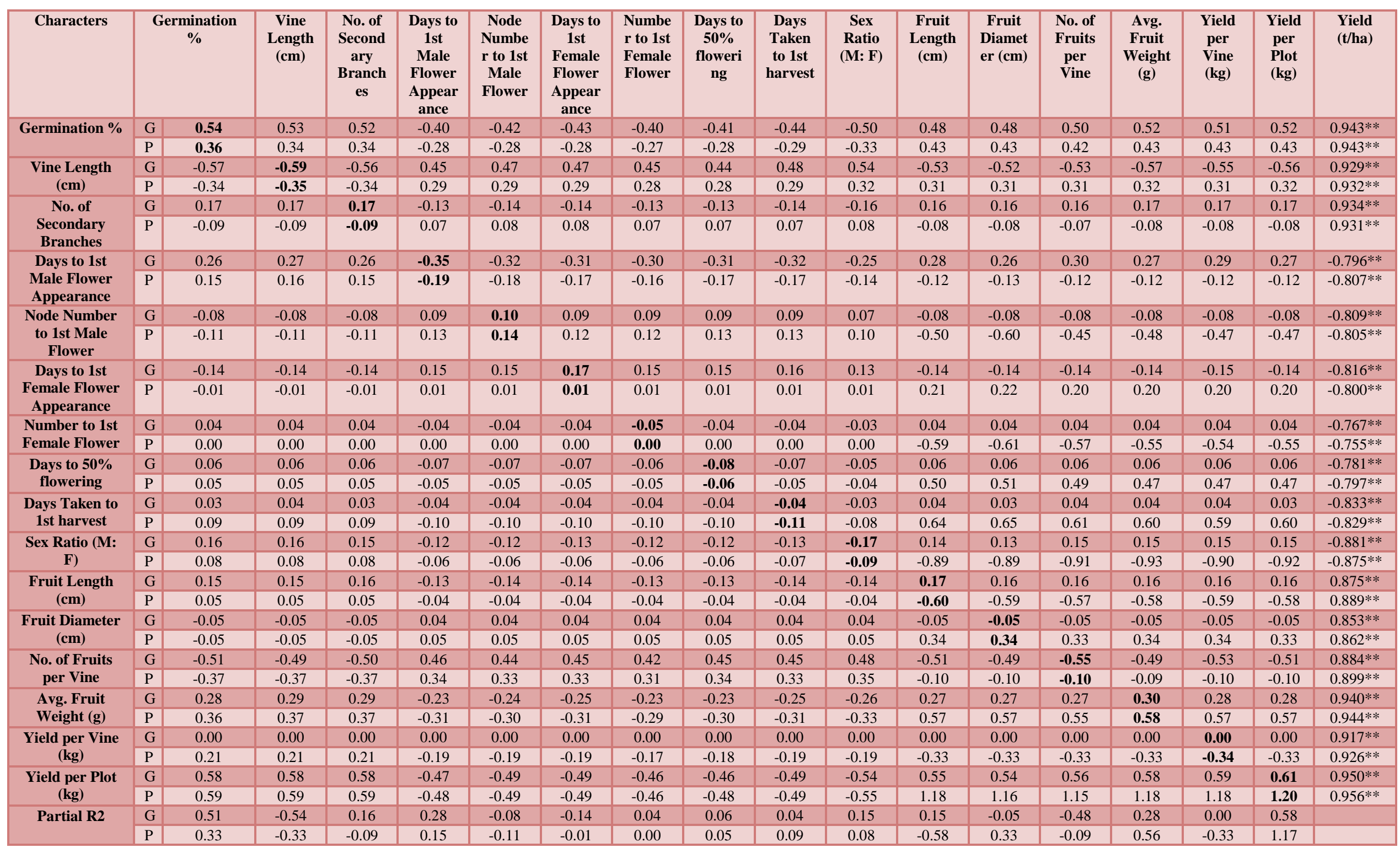


Table.6 Clustering pattern of 16 genotypes on the basis of Mahalanobis $\mathrm{D}^{2}$ statistics

\begin{tabular}{|c|c|l|}
\hline Cluster number & No. of genotypes & \multicolumn{1}{|c|}{ Genotypes } \\
\hline I & 5 & Maharaja, CCH-1, SL-40, Prasad-100 and Super Kheera 40 \\
\hline II & 7 & $\begin{array}{l}\text { Moti, Super green,Rani, Barsati No. 12, Farmer variety, Kohinoor } \\
\text { and Local variety }\end{array}$ \\
\hline III & 1 & SwarnAgati \\
\hline IV & 3 & F-999, Sun -L Heena \\
\hline
\end{tabular}

Table.7 Average of intra- and inter- clusters $\mathrm{D}^{2}$ values for five clusters

\begin{tabular}{|l|c|c|c|c|}
\hline & Cluster 1 & Cluster 2 & Cluster 3 & Cluster 4 \\
\hline Cluster 1 & 41.5 & 250.05 & 142.91 & 986.25 \\
\hline Cluster 2 & 250.05 & 68.92 & 666.2 & 358.82 \\
\hline Cluster 3 & 142.91 & 666.2 & 0 & 1745.4 \\
\hline Cluster 4 & 986.25 & 358.82 & 1745.4 & 98.99 \\
\hline
\end{tabular}

Table.8 Intra-cluster group means for seventeen parameters in cucumber

\begin{tabular}{|c|c|c|c|c|c|c|c|c|c|c|c|}
\hline & $\begin{array}{c}\text { Germination } \\
\%\end{array}$ & $\begin{array}{c}\text { Vine } \\
\text { Length } \\
\text { (cm) }\end{array}$ & $\begin{array}{c}\text { No. of } \\
\text { Secondary } \\
\text { Branches }\end{array}$ & $\begin{array}{l}\text { Days to 1st } \\
\text { Male } \\
\text { Flower } \\
\text { Appearance }\end{array}$ & $\begin{array}{c}\text { Node } \\
\text { Number } \\
\text { to } 1 \text { st } \\
\text { Male } \\
\text { Flower }\end{array}$ & $\begin{array}{l}\text { Days to 1st } \\
\text { Female } \\
\text { Flower } \\
\text { Appearance }\end{array}$ & $\begin{array}{c}\text { Node } \\
\text { Number } \\
\text { to } 1 \text { st } \\
\text { Female } \\
\text { Flower }\end{array}$ & $\begin{array}{c}\text { Days to } \\
50 \% \\
\text { flowering }\end{array}$ & $\begin{array}{c}\text { Days } \\
\text { Taken } \\
\text { to } 1 \mathrm{st} \\
\text { harvest }\end{array}$ & $\begin{array}{c}\text { Sex } \\
\text { Ratio } \\
\text { (M: } \\
\text { F) }\end{array}$ & $\begin{array}{c}\text { Fruit } \\
\text { Length } \\
\text { (cm) }\end{array}$ \\
\hline Cluster 1 & 80.05 & 181.34 & 15.15 & 34.64 & 3.26 & 41.53 & 5.18 & 44.44 & 51.08 & 3.07 & 21.73 \\
\hline Cluster 2 & 73.26 & 157.1 & 11.71 & 37.28 & 4.21 & 44.77 & 6.64 & 47.91 & 55.07 & 3.37 & 16.33 \\
\hline Cluster 3 & 85.58 & 191.17 & 17.1 & 32.67 & 2.29 & 39.33 & 4.56 & 42.08 & 48.38 & 2.69 & 24.11 \\
\hline Cluster 4 & 61.76 & 125.52 & 7.78 & 38.5 & 4.6 & 46.22 & 7.22 & 49.46 & 56.86 & 4.33 & 13.91 \\
\hline
\end{tabular}


Table.9 Intra-cluster group means for seventeen parameters in cucumber

\begin{tabular}{|l|c|c|c|c|c|c|}
\hline & $\begin{array}{c}\text { Fruit } \\
\text { Diameter (cm) }\end{array}$ & $\begin{array}{c}\text { No. of Fruits } \\
\text { per Vine }\end{array}$ & $\begin{array}{c}\text { Avg. Fruit } \\
\text { Weight (g) }\end{array}$ & $\begin{array}{c}\text { Yield per } \\
\text { Vine (kg) }\end{array}$ & $\begin{array}{c}\text { Yield per } \\
\text { Plot (kg) }\end{array}$ & $\begin{array}{c}\text { Yield } \\
\text { (t/ha) }\end{array}$ \\
\hline Cluster 1 & 6.98 & 18.69 & 148.64 & 2.64 & 12.02 & 44.54 \\
\hline Cluster 2 & 4.89 & 14.01 & 126.11 & 1.57 & 8.96 & 37.77 \\
\hline Cluster 3 & 7.76 & 22.98 & 157.79 & 3.49 & 15.24 & 51.17 \\
\hline Cluster 4 & 3.89 & 10.23 & 100.07 & 0.9 & 4.86 & 28.25 \\
\hline
\end{tabular}

Table.10 Per cent contribution in seventeen characters towards total genetic divergence in cucumber

\begin{tabular}{|c|c|c|c|}
\hline S. No. & Source & Contribution \% & Times ranked 1st \\
\hline $\mathbf{1}$ & Germination \% & 0 & 0.00 \\
\hline $\mathbf{2}$ & Vine Length (cm) & 1.67 & 2.00 \\
\hline $\mathbf{3}$ & No. of Secondary Branches & 0 & 0.00 \\
\hline $\mathbf{4}$ & Days to 1st Male Flower & 0 & 0.00 \\
\hline & Appearance & 0 & 0.00 \\
\hline $\mathbf{5}$ & Node Number to 1st Male Flower & 1.67 & 2.00 \\
\hline $\mathbf{6}$ & Days to 1st Female Flower & & \\
\hline $\mathbf{7}$ & Appearance & 0 & 0.00 \\
\hline & Node Number to 1st Female & & 0.00 \\
\hline $\mathbf{8}$ & Flower & 5 & 6.02 \\
\hline $\mathbf{9}$ & Days to 50\% flowering & 20 & 24.10 \\
\hline $\mathbf{1 0}$ & Sex Ratio (M: F) & 15 & 12.07 \\
\hline $\mathbf{1 2}$ & Fruit Length (cm) & 10 & 0.00 \\
\hline $\mathbf{1 3}$ & Fruit Diameter (cm) & 0 & 7.02 \\
\hline $\mathbf{1 4}$ & No. of Fruits per Vine & 5.83 & 10.04 \\
\hline $\mathbf{1 5}$ & Avg. Fruit Weight (g) & 8.33 & 24.10 \\
\hline $\mathbf{1 6}$ & Yield per Vine (kg) & 20 & 15.06 \\
\hline $\mathbf{1 7}$ & Yield per Plot (kg) & 12.5 & \\
\hline & Yield (t/ha) & & \\
\hline
\end{tabular}


Genetic variability, GCV, PCV, heritability, genetic advance and genetic advance as percent of mean

The simple measure of variability like mean, phenotypic and genotypic coefficients of variation (PCV and GCV), heritability in broad sense genetic advance and genetic advance as percent of mean is presented in Table 3. Higher magnitude of genotypic coefficient of variance GCV and phenotypic coefficient of variance was recorded for node number to 1 st male flower (20.092 \& 21.421), fruit length $(\mathrm{cm})(20.392 \& 21.210)$, fruit diameter $(\mathrm{cm})(26.142 \& 28.082)$, no. of fruits per vine (25.761 \& 26.545), yield per vine $(\mathrm{kg})(42.791 \& 43.156)$ and yield per plot $(\mathrm{kg})$ (32.554 \& 33.07). The heritability estimate were found to be high (>60) for almost all the characters viz., germination \% (95.900),vine length $(\mathrm{cm})$ (97.900), no. of secondary branches(96.500), days to 1st male flower appearance (84.100), node number to 1st male flower (88.000), days to 1 st female flower appearance(85.800), number to 1 st female flower (80.200), days to $50 \%$ flowering (80.000), days taken to 1st harvest (88.100), sex ratio (m: f) (97.700), fruit length $(\mathrm{cm})$ (92.400), fruit diameter $(\mathrm{cm})(86.700)$, no. of fruits per vine(94.200), avg. fruit weight $(\mathrm{g})$ (96.100), yield per vine (kg) (98.300),yield per plot (kg) (96.900) and yield (t/ha) (92.500). The highest Genetic advance was recorded for characters like Vine Length $(\mathrm{cm})$ (47.572) and Avg. Fruit Weight (g) (40.930). The genetic advance as per cent of mean was highest for germination \%(20.694),vine length $(\mathrm{cm})$ (29.569), no. of secondary branches (50.525), node number to 1st male flower (38.821), number to 1st female flower (32.706), sex ratio (m: f)(31.724), fruit length (cm) (40.388), fruit diameter $(\mathrm{cm})(50.132)$, no. of fruits per vine(51.501), avg. fruit weight $(\mathrm{g})$ (31.425), yield per vine $(\mathrm{kg})$ (87.405), yield per plot (kg) (66.007) and yield (t/ha) (35.256).

\section{Genotypic and phenotypic correlation} coefficient analysis

In the present investigation the genotypic and phenotypic correlation coefficient of different characters with fruit yield (t ha-1) and their relationship among themselves are presented in table 4. Genotypic correlation coefficient analysis revealed that yield ( $t / h a)$ showed positive significant association with Germination \% $(0.943 * *)$ Vine Length $(\mathrm{cm})$ $(0.929 * *)$, No. of Secondary Branches $(0.934 * *)$, Fruit Length $(\mathrm{cm})\left(0.875^{* *}\right)$, Fruit Diameter $(\mathrm{cm})\left(0.853^{* *}\right)$, No. of Fruits per Vine $(0.884 * *)$, Avg. Fruit Weight $(\mathrm{g})$ $(0.940 * *)$, Yield per Vine $(\mathrm{kg})(0.917 * *)$ and Yield per Plot $(\mathrm{kg})\left(0.950^{* *}\right)$ where as the phenotypic correlation coefficient analysis revealed that Yield ( $t / h a)$ showed positive significant association with Germination \% $(0.943 * *)$, Vine Length $(\mathrm{cm})(0.932 * *)$, No. of Secondary Branches $(0.931 * *)$, Fruit Length $(\mathrm{cm})(0.889 * *)$, Fruit Diameter $(\mathrm{cm})$ $(0.862 * *)$, No. of Fruits per Vine $(0.899 * *)$, Avg. Fruit Weight (g) $\left(0.944^{* *}\right)$, Yield per Vine $(\mathrm{kg})\left(0.926^{* *}\right)$ and Yield per Plot $(\mathrm{kg})$ $\left(0.956^{* *}\right)$.

\section{Genotypic and phenotypic path coefficient analysis}

The genotypic and phenotypic path coefficient among the different fruit yield ( $t$ ha-1) traits in cucumber was worked out to assess the association among themselves. Perusal of Table-5. Genotypic path coefficient analysis revealed that the direct positive effect on fruit yield ( $t$ ha-1) was exhibited by germination \%(0.54), no. of secondary branches (0.17), node number to 1st male flower (0.10), days to 1 st female flower appearance $(0.17)$, fruit length $(\mathrm{cm})(0.17)$, avg. fruit weight $(\mathrm{g})(0.30)$, yield per vine $(\mathrm{kg})(0.00)$ and yield per plot $(\mathrm{kg})(0.61)$. where as the phenotypic path coefficient analysis revealed that the direct positive effect 
on fruit yield ( $\mathrm{t}$ ha-1) was exhibited by germination $\%(0.36)$, node number to $1 \mathrm{st}$ male flower (0.14), days to 1 st female flower appearance $(0.1)$, number to 1 st female flower (0.000), fruit diameter $(\mathrm{cm}(0.34)$, avg. fruit weight (g) (0.58) and yield per plot $(\mathrm{kg})(1.20)$.

\section{Genetic diversity (D2) analysis}

Clustering pattern of eighteen genotype of cucumber were grouped into clusters following Mohalanobis $\mathrm{D}^{2}$ analysis (Table 6) Clustering pattern indicated that cluster II is largest cluster comprising 7 out of sixteen genotype. On the other hand cluster I, comprised 5 genotype, cluster III comprised genotypes 1 and cluster IV cluster comprised 3 genotype. The pattern of group constellation proved the existence of significant amount of variability. The distribution of genotypes also indicated that the genotypes originated from different states were grouped into same cluster and genotypes of same states into different clusters. The inter and intra average distances among five clusters were computed and have been given in the Table.7. The inter cluster distance was maximum between cluster II and IV (1745.4) followed by cluster I and Cluster IV (986.25), Cluster II and cluster III (666.2), cluster I and II (250.05), Cluster I and III (142.91). A comparison of the mean value of seventeen characters of different clusters has been presented in Table (7). Considerable differences in cluster mean values were evident for all the characters. Cluster I, II, III and IV was characterized by high mean value for vine length and low mean values for yield per vine $(\mathrm{kg})$. The percent contribution of sixteen characters towards total genetic divergence is listed in Table.9. The selection and choice of parents mainly depends upon contribution of characters towards divergence. In the present investigation the highest contribution in manifestation of genetic divergence was exhibited by Sex Ratio (M: F) (20), Yield (t/ha) (12.5), Fruit Length (cm) (15), Fruit Diameter (cm) (10), Avg. Fruit Weight (g) (5.83), Yield per Vine (kg) (8.33), Yield per Plot (kg) (20), Days to 1st Female Flower Appearance (1.67) and Vine Length $(\mathrm{cm})(1.67)$. In other words, selection for these characters may be rewarding.

From the present study it is concluded that cucumber genotypes under investigation showed significant genetic variability. Based on mean performance for fruit yield per plant $(3.49 \mathrm{~kg})$, fruit yield per plot $(15.24 \mathrm{~kg})$ and fruit yield (51.17t ha-1) was found in Swarn Agati genotypes were considered suitable genotypes in Prayagraj climatic condition.

\section{References}

Ahmed, N.C.B., and I.M.W. Khaliq., (2007) Thebinheritance of yield and yield components of five wheat hybrid populations under drought conditions. Indonesian Journal of Agricultural Science, 8(2): 53-59.

Deakin, J.R., G.W. Bohn, and T.W. Whitaker. 1971 Interspecific hybridization in Cucumis. Econ. Bot. 25:195-211

Golabadi, M., Golkar, P. and Eghtedary, A. R. 2012. Assessment of genetic variation in cucumber (Cucumis sativus L.) genotypes. European Journal of Experimental Biology, 2(5):1382-1388.

Kumar R., Rajasree V., Praneetha S., Rajeswari S. and Tripura U. (2018). Correlation and Path Coefficient Analysis Studies in Pumpkin (Cucurbita moschataDuch. Ex poir) for Yield and Quality Traits. Int.J.Curr.Microbiol.App.Sci (2018) 7(5): 3067-3075

Kumar Rahul, Munshi A.D., Behera T.K., Talukdar A., Choudhary H. and Dash P. (2018). Assessment of Genetic Variability among 78 Cucumber 
(Cucumis sativus L.) Germplams. Int.J.Curr.Microbiol.App.Sci (2018) 7(5): 117-126

Kumar Sandeep, DharminderKumar, Ramesh Kumar, KS Thakur, Balbir Singh Dogra (2013). "Estimation of Genetic Variability and Divergence for Fruit Yield and Quality Traits in Cucumber (Cucumis Sativus L.) in North-Western Himalays," Universal Journal of Plant Science, Vol. 1, No. 2, pp. 27 - 36,

Pandey, S., Ansari, W. A., Mishra, V. K., Singh, A. K., Singh, M., 2013, Genetic diversity in Indian cucumber based on microsatellite and morphological markers. Biochem Syst Ecol., 51:19-27.

Ranjan, P., Gangopadhay, K. K., Bag, M. K., Roy, A., Srivastava, R., Bhardwaj, R. and Dutta, M. 2015. Evaluation of cucumber (Cucumis sativus L.) germplasm for agronomic traits and disease resistance and estimation of genetic variability. Indian J. Agril. Sci. 85(2): 234-239.

Ullah, M. Z., Hasan, M. J., Chowdhury, A. Z. K. M. A., Saki, A. I. and Rahman, A. H. M. A., (2012) Genetic variability and correlation in exotic cucumber (Cucumis sativus L.) varieties. Bangladesh J. Pl. Breed. Genet., 25(1): 17-23.

Veena, R., Sidhu, A. S., Pitchaimuthu, M. and Souravi, K., 2012, Genetic evaluation of Cucumber (Cucumis sativus L.) genotypes for some yield and related traits. Elec J Pl Bre 3(3): 945-948.

\section{How to cite this article:}

Yogesh Kumar, Samir Ebson Topno and Vijay Bahadur. 2021. Study on Genetic Variability, Heritability and Genetic Divergence for Character Association in Cucumber (Cucumis sativus L.) under Prayagraj Agro - Climatic Conditions. Int.J.Curr.Microbiol.App.Sci. 10(01): 32393248. doi: https://doi.org/10.20546/ijcmas.2021.1001.377 